\title{
Evaluation of Probability Distribution Technique for Predication of Weekly Maximum Rainfall and Crop Planning for North Bihar
}

\author{
Sanjay Kumar Nirala*, Sushil Kumar Roy and Sujeet Kumar Bhagat \\ Department of Soil and Water Engineering, College of Agriculture Engineering, Dr. \\ R.P.C.A.U., Pusa (Samastipur) Bihar-848125, India \\ *Corresponding author
}

\section{A B S T R A C T}

Probability distribution technique used to predict the weekly maximum rainfall. In India

Keywords

Probability

distribution, Weekly

maximum rainfall,

Crop planning, Chi

Square test

Article Info

Accepted:

18 August 2018

Available Online:

10 September 2018

$60 \%$ of total net sown area comes under rainfed. More than $65 \%$ population depends on agriculture, but, it contributes only $15.7 \%$ GDP of India. The rainfall distribution in country is non uniform which varies from place to place as well as time to time, therefore, study of probability distribution technique needed for understand rainfall characteristic and distribution. Appropriate analysis of rainfall data of 32 years from 1980 to 2011 was done for North Bihar. It was found that maximum rainfall $223 \mathrm{~mm}$ at $10 \%$ probability level minimum $2.57 \mathrm{~mm}$ at $90 \%$ probability level during $26^{\text {th }}$ week and. Gumbel Distribution technique has found to be best suitable for evaluating weekly maximum rainfall up to $80 \%$ probability level by Chi Square Test. Crop planning at $80 \%$ probability level was considered, since an appreciable amount of rainfall is available from 25 to 38 week and maximum rainfall. In pusa region for Kharif season rice crop varieties such as Prabhat, Bhagavati for up land and Saroj, Rajendra Kasutri, Rajendra Subhashni, for low land are may be suitable. For Rabi season wheat, Maize, Mustard, Rai, Tori, crop suitable for upland and lowland.

\section{Introduction}

Rainfall is one of the most important natural resource input to crop production in the tropical and subtropical region. Importance of probability distribution technique to predict rainfall can be understand by the fact that in India $60 \%$ of total net sown area comes under rainfed land. Despite this progress, marginal and small farmers constituting $80 \%$ of agricultural income group, still depend on rainfed farming. But it contributes only $15.7 \%$ GDP of India (2010) www.worldagriculture. com, www.wikipedia.com). One of the most important problems in hydrology deals with interpreting a post record of hydrology event in future probability of occurrences. This problem arises in the estimation of frequencies of flood, drought, rainfall etc. Probability and frequency analysis of rainfall data enables us to determine the expected rainfall at various chances.

Bhakar et al., (2006) calculated frequency analysis of consecutive days maximum rainfall. They tested by comparing the Chi- 
squre value and found that Gama Distribution was best fit for Banswara, Rajsthan region. Panda et al., (2009) analysed distribution functions for rainfall data (1969-2007) of Koraput district of Orissa for judicious crop planning. They found that there is only 4.3 $\mathrm{mm}$ rainfall available during rabi season at $70 \%$ probability level. They deduced that a suitable combination of crops like wheat+tomato, wheat+potato, tomato+bean and potato+cabbage can be successfully grown by the farmers during rabi season from the harvested water. Singh et al., (2009) analysed variation of seasonal rainfall and probabilities of occurrence of assured weekly rainfall provide useful information for efficient agricultural management. They studied seven stations of Himachal Pradesh have been selected for the analysis of the rainfall data. They applied probability distribution revealed that high rainfall belt is located in the north western part of the state. For better apple production, monsoon rainfall plays significant role. Chand et al., (2011) analysed of rainfall data for 34 year (19752008) Jhansi distric of Bundelkhand agroclimatic zone of U.P. They analysed to weekly monthly seasonal and annual probability at different levels of rainfall for suitable crop planning. They found $70 \%$ of initial probability of a dry week from 1 to 24th week and wet week 26 to 37th week. Jhakhar et al., (2011) analysed the probability distribution of rainfall characteristic of Semiliguda in Koraput Orissa they applied Weibull's method and approximately closely the linear relationship between the rainfall and plotting position they found occurrence of $75 \%$ probable rainfall in Kharif summer and Rabi season are $1095.5 \mathrm{~mm} 91.4 \mathrm{~mm}$ and $83 \mathrm{~mm}$ respectively then selection of seed bad preparation, crop verities and choice of crop pattern. The specific objectives of study are prediction the observed weekly rainfall at different probability levels using Weibull's method, evaluation probability distribution technique to predict weekly maximum rainfall and development of crop planning based on predicated weekly rainfall for Pusa Samastipur, Bihar.

\section{Materials and Methods}

The study area is selected at Pusa, Samastipur, Bihar, India at a Reference Level of $52 \mathrm{~m}$ above the M.S.L at $25.98^{\circ} \mathrm{N}$ latitude and $85.67^{\circ} \mathrm{E}$ longitude and the climate is a humid subtropical. Altitude of the site is $52.92 \mathrm{~m}$ above mean sea level. Experimental site is under humid sub-tropical climate, greatly influenced by the south-west monsoon. The main characteristic of the climate is hot-dry summer followed by cold winters. Average annual rainfall is $1270 \mathrm{~mm}$, out of which about $1026 \mathrm{~mm}$ is received during the monsoon season from June to October. Soil type is sandy clay loam with average available moisture content $12.01 \%$. The daily rainfall data of 32 years (1980-2011) were collected from metrological observatory location in Pusa for study purposes.

\section{Evaluation of probability distribution technique for prediction of weekly maximum rainfall}

\section{Weibull's distribution}

The weekly rainfall data were analysed for computation of weekly probable rainfall amount at 10, 20, 30, 40, 50, 60, 70, 80 and 90 percentage probability levels by using Weibull equation.

$$
=\frac{M}{(N+1)}
$$

$\mathrm{P} \quad \ldots 1$

Where, $\mathrm{P}=$ Probability (friction), $\mathrm{T}=$ Return period, $\mathrm{M}=$ rank of the observed rainfall, $\mathrm{N}=$ total number of year recorded 


\section{Gumble distribution}

Gumbel distribution defined a weekly maximum Rainfall of 52 week and annual series of maximum Rainfall. According to this theory of extreme event the probability of occurrence of an event equal to or larger than value $\mathrm{X}$ is

$$
P\left(X \geq X_{0}\right)=1-e^{-e^{-y}}
$$

In which y is a dimension variable given by

$$
\begin{array}{cc}
\begin{array}{c}
y=a(\mathrm{X}-\overline{\mathrm{X}}) \quad \bar{X} \\
, \mathrm{a}=-0.450056 \sigma_{\mathrm{x}} \ldots 3
\end{array} \\
\mathrm{Y}=\frac{1.285(\mathrm{X}-\overline{\mathrm{X}})}{\sigma \mathrm{x}} & \\
\bar{X} & +0.577 \ldots 4
\end{array}
$$

\section{$\bar{X}$}

Where, $\quad=$ mean of variant $\sigma \mathrm{x}=$ standard deviation of variant $X$

In paretic it is the value of $\mathrm{x}$ for a given $\mathrm{P}$ that is required and as such eqn. is tramped as

$Y_{P=\ln [\ln (1-P)]}$

Noting that the return period $\mathrm{T}=\frac{1}{P}$ and designating

$$
\left[\ln \cdot \ln \frac{T}{T-1}\right]
$$

$\mathrm{Y}_{\mathrm{T}}=-$

The value of variate $\mathrm{X}$ with a return period $\mathrm{T}$ is

$$
\left.\mathrm{X}_{\mathrm{T}=} \overline{\mathrm{X}}+K \sigma_{n-1}\right)
$$

Where, ${ }^{\sigma_{n-1}}=$ Standard deviation of the sample of size $\mathrm{N}=\sqrt{\frac{\Sigma(x-\bar{X})^{2}}{N-1}} \ldots 8$

$\mathrm{K}=$ Frequency factor expressed as

$\mathrm{K}={ }^{\frac{Y_{l-\overline{Y_{n}}}}{S_{n}}} \ldots .9$

$\bar{Y}_{n}$

$=$ reduced mean, a function of sample size $\mathrm{N}$

$\mathrm{N} \rightarrow \infty, \quad \bar{Y}_{n} \quad \rightarrow 0.557$

$\mathrm{S}_{\mathrm{n}}=$ reduced standard deviation a function of sample size $\mathrm{N}$ for $\mathrm{N} \rightarrow \infty, \mathrm{S}_{\mathrm{n}} \rightarrow 1.2825$

\section{Log Pearson type-III distribution}

The Log Pearson Type III Distribution is statically technique for predication of extreme rainfall value at different probability level.

In this the variety first transformed into logarithmic form (base 10) and transformed data is then analysed if $\mathrm{x}$ is the variant of a random hydrologic series then the series of $\mathrm{Z}$ varieties.

Where,

$Z=\log x \ldots 10$

Are first obtained for this $\mathrm{Z}$ series for any recurrence interval

$\mathrm{Z}_{\mathrm{T}}=\overline{\mathrm{Z}}+\mathrm{K}_{\mathrm{Z}} \sigma_{\mathrm{z}} \ldots 11$

Where, $\mathrm{K}_{\mathrm{z}}=$ Coefficient a frequency factor which is function of recurrence interval $\mathrm{T}$ and the coefficient of skew $\mathrm{C}_{\mathrm{s}}$ 
$\sigma_{\mathrm{z}}=$ Standard deviation of the $\mathrm{Z}$ variant Sample

$\sigma_{\mathrm{z}}=\sqrt{\frac{\sum(\mathrm{Z}-\overline{\mathrm{Z}})^{2}}{(\mathrm{~N}-1)}} \ldots 12$

$\mathrm{C}_{\mathrm{s}}=$ Coefficient of skew of variant $\mathrm{Z}$

$=\frac{N \sum(Z-\bar{Z})^{2}}{(N-1)(N-2)\left(\sigma_{Z}\right)^{2}} \ldots 13$

$\overline{\mathrm{Z}}=$ Mean of the $\mathrm{Z}$ values, $\mathrm{N}=$ Sample size $=$ Number of week of record

The variation of $\mathrm{Kz}=\mathrm{f}(\mathrm{Cs}, \mathrm{T}) ; \mathrm{X}_{\mathrm{T}}=$ antilog $\left(\mathrm{Z}_{\mathrm{T}}\right)$

\section{Chi-square test of goodness of fit}

The chi-square test is used to determine whether there is a significant difference between the expected frequencies and the observed frequencies in one or more categories.

It is known as " chi-square goodness of fit" it enable us to find if the deviation to the experiment from theory is just by chance or is it really due to the inadequacy of the theory to fit the observed data.

If $\mathrm{O}_{\mathrm{i}}(\mathrm{i}=1,2 \ldots \mathrm{n})$ is a set of observed frequency and $\mathrm{E}_{\mathrm{i}} \quad(\mathrm{i}=1, \quad 2 \ldots . . \mathrm{n})$ is corresponding set of expected frequency then Karl Pearson's Chi-square given by

$\chi^{2}=\sum_{1}^{n} \frac{\left(O_{i}-E_{i}\right)^{2}}{E_{i}}$

The distribution having the least sum of the Chi square $\left(\chi^{2}\right)$ value for all probability level is judged best.

\section{Results and Discussion}

\section{Observed rainfall amount}

The weekly rainfall values were calculated using Weibull method at various recurrence intervals i.e.10, 5, 3.33, 2.5, 2, 1.6, 1.42, 1.25, $1.11,1.01$ years, are present in table 2. The table value indicates that there is a large variation in observed value among all different probability levels 10\%, 20\%, 30\%, 40\%, 50\%, $60 \%, 70 \%, 80 \%, 90 \%$. At $80 \%$ probability level the range of maximum and minimum observed weekly rainfall was obtained as $17.28 \mathrm{~mm}$ and $0 \mathrm{~mm}$ respectively, similarly the value of maximum rainfall equal to 223 , $181,132,83.36,68.3,45.76,28.73,17.28$ and10 mm were obtained at 10\%, 20\%, 30\%, $40 \%, 50 \%, 60 \%, 70 \%, 80 \%$ and $90 \%$ probability level respectively.

\section{Expected weekly rainfall amount}

The expected maximum weekly rainfall values were computed using Log-Person Type-III distribution,

Normal distribution and Gumbel distribution for different probability levels. The obtained results and present in table 1 .

The expected weekly maximum rainfall at different probability level found with help of Gumble distribution shown in table 1.

Sander deviation $(\sigma)=125.32$, Mean $(\bar{X})=$ 118.4

Log Pearson Type III distribution used for predicts weekly maximum rainfall. The obtained expected rainfall value at different probability level represented in table 1 . Average $\quad(\log x)=Z=1.789, \quad$ Standard deviation of $Z=0.545$, Skewness coefficient $\left(C_{\mathrm{s}}\right)=-0.1502$ It was expected that weekly max rainfall for different probability level 
$10 \%, 20 \%, 30 \%, 40 \%, 50 \%, 60 \%, 70 \%, 80 \%$ and $90 \%$ are $293.87,174.30,123.50,87.52$, $62.02,42.87,30.24,21.11$ and $11.80 \mathrm{~mm}$ respectively.

Log Normal Distribution is statically method also used for prediction weekly maximum rain fall at different probability level. The obtained results are shown in table 1 .
Average $(\log \mathrm{x})=\mathrm{Z}=1.789$, Standard deviation of $Z=0.545$, Skewness coefficient $\left(\mathrm{C}_{\mathrm{s}}\right)=0$

The weekly maximum expected rainfall at different probability level 10\%, 20\%, 30\%, $40 \%, 50 \%, 60 \%, 70 \%, 80 \%, 90 \%$, are 300.59 , $172.99,121.61,85.48,60.10,42.25,29.71$, $20.88,12.01$, respectively.

Table.1 Computed values of observed and theoretical weekly maximum rainfall and there goodness of fit by Chi -squire value for maximum rainfall

\begin{tabular}{|c|c|c|c|c|c|c|c|c|}
\hline \multirow{2}{*}{$\begin{array}{c}\text { Probabil } \\
\text { ity } \\
(\%)\end{array}$} & \multirow{2}{*}{$\begin{array}{l}\text { Return } \\
\text { period } \\
\text { (years) }\end{array}$} & \multirow{2}{*}{$\begin{array}{l}\text { Observe } \\
\text { d max } \\
\text { weekly } \\
\text { rainfall } \\
(x)(\mathrm{mm})\end{array}$} & \multicolumn{3}{|c|}{ Expected weekly maximum rainfall } & \multicolumn{3}{|c|}{ Chi-square } \\
\hline & & & $\begin{array}{c}\text { Gumbel } \\
\text { Distribut } \\
\text { ion } \\
(\mathbf{m m})\end{array}$ & $\begin{array}{c}\text { Log } \\
\text { Pearson } \\
\text { Type III } \\
\text { Distribution } \\
(\mathbf{m m})\end{array}$ & $\begin{array}{l}\text { Log Normal } \\
\text { Distribution } \\
\quad(\mathrm{mm})\end{array}$ & $\begin{array}{c}\text { Gumbel } \\
\text { Distribut } \\
\text { ion }\end{array}$ & $\begin{array}{c}\text { Log } \\
\text { Pearson } \\
\text { Type III } \\
\text { Distribution }\end{array}$ & $\begin{array}{l}\text { Log Normal } \\
\text { Distribution }\end{array}$ \\
\hline 10 & 10 & 307.78 & 301.57 & 293.87 & 300.59 & 0.127 & 0.658 & 0.172 \\
\hline 20 & 5 & 248.06 & 220.66 & 174.30 & 172.99 & 3.40 & 31.21 & 32.57 \\
\hline 30 & 3.33 & 168.47 & 170.27 & 123.50 & 121.61 & 0.019 & 16.37 & 18.05 \\
\hline 40 & 2.5 & 104.92 & 132.15 & 87.52 & 85.49 & 5.61 & 3.46 & 4.42 \\
\hline 50 & 2 & 47.5 & 98.77 & 62.02 & 60.10 & 26.61 & 3.399 & 2.64 \\
\hline 60 & 1.66 & 40.52 & 68.72 & 42.87 & 42.25 & 11.57 & 0.13 & 0.07 \\
\hline 70 & 1.42 & 26.05 & 39.17 & 30.24 & 29.71 & 4.399 & 0.58 & 0.45 \\
\hline 80 & 1.25 & 19.66 & 8.10 & 21.11 & 20.88 & 16.49 & 0.10 & 0.07 \\
\hline 90 & 1.11 & 11.79 & -30.98 & 11.81 & 12.02 & -59.05 & 1.83 & 0.0043 \\
\hline & & & & & $\begin{array}{l}\text { Total }\left(\chi^{2}\right) S \\
\text { value }\end{array}$ & 9.18 & 55.91 & 58.45 \\
\hline
\end{tabular}


Table.2 Weekly rainfall at different probability level

\begin{tabular}{|c|c|c|c|c|c|c|c|c|c|c|}
\hline \multirow[t]{2}{*}{ Weeks } & \multicolumn{10}{|c|}{ Probability } \\
\hline & $10 \%$ & $20 \%$ & $30 \%$ & $40 \%$ & $50 \%$ & $60 \%$ & $70 \%$ & $80 \%$ & $90 \%$ & $100 \%$ \\
\hline 1 & 4 & 1.94 & 0 & 0 & 0 & 0 & 0 & 0 & 0 & 0 \\
\hline 2 & 10.27 & 0 & 0 & 0 & 0 & 0 & 0 & 0 & 0 & 0 \\
\hline 3 & 10.78 & 0 & 0 & 0 & 0 & 0 & 0 & 0 & 0 & 0 \\
\hline 4 & 13.1 & 4.22 & 0 & 0 & 0 & 0 & 0 & 0 & 0 & 0 \\
\hline 5 & 10.67 & 3.08 & 0 & 0 & 0 & 0 & 0 & 0 & 0 & 0 \\
\hline 6 & 6.4 & 2.52 & 0.14 & 0 & 0 & 0 & 0 & 0 & 0 & 0 \\
\hline 7 & 17.45 & 6.26 & 0.48 & 0 & 0 & 0 & 0 & 0 & 0 & 0 \\
\hline 8 & 0 & 0 & 0 & 0 & 0 & 0 & 0 & 0 & 0 & 0 \\
\hline 9 & 8.27 & 3.72 & 0.17 & 0 & 0 & 0 & 0 & 0 & 0 & 0 \\
\hline 10 & 4.09 & 0.16 & 0 & 0 & 0 & 0 & 0 & 0 & 0 & 0 \\
\hline 11 & 2.68 & 0.12 & 0 & 0 & 0 & 0 & 0 & 0 & 0 & 0 \\
\hline 12 & 9.25 & 1 & 0 & 0 & 0 & 0 & 0 & 0 & 0 & 0 \\
\hline 13 & 4.82 & 0.92 & 0 & 0 & 0 & 0 & 0 & 0 & 0 & 0 \\
\hline 14 & 12.9 & 1.92 & 0 & 0 & 0 & 0 & 0 & 0 & 0 & 0 \\
\hline 15 & 7.16 & 0.04 & 0 & 0 & 0 & 0 & 0 & 0 & 0 & 0 \\
\hline 16 & 21.84 & 12.6 & 6.15 & 0 & 0 & 0 & 0 & 0 & 0 & 0 \\
\hline 17 & 18.91 & 11.92 & 7.96 & 4.72 & 0 & 0 & 0 & 0 & 0 & 0 \\
\hline 18 & 26.6 & 20.18 & 14.29 & 6.32 & 0.5 & 0 & 0 & 0 & 0 & 0 \\
\hline 19 & 48.73 & 32.34 & 15.67 & 10.3 & 3.3 & 0.62 & 0 & 0 & 0 & 0 \\
\hline 20 & 41.22 & 25.44 & 17 & 5.6 & 2.35 & 0.08 & 0 & 0 & 0 & 0 \\
\hline 21 & 91.55 & 54.46 & 38.03 & 21.72 & 13.35 & 3.84 & 0 & 0 & 0 & 0 \\
\hline 22 & 49.72 & 39.02 & 26.95 & 17.74 & 13.75 & 10.06 & 0.18 & 0 & 0 & 0 \\
\hline 23 & 99.28 & 72.5 & 42 & 21.66 & 13.3 & 6.48 & 2.94 & 0 & 0 & 0 \\
\hline 24 & 96.6 & 56.96 & 38.74 & 22.24 & 11.5 & 8.6 & 4.86 & 0 & 0 & 0 \\
\hline 25 & 120.26 & 78.98 & 71.16 & 55.28 & 39.5 & 23.76 & 18.98 & 6.98 & 0 & 0 \\
\hline 26 & 223.83 & 135.8 & 92 & 65.24 & 37.25 & 27.26 & 18.75 & 9.22 & 3 & 0 \\
\hline 27 & 211.08 & 181.6 & 132.45 & 76.56 & 59.95 & 40.68 & 20.36 & 11.56 & 3.15 & 1.13 \\
\hline 28 & 211.28 & 142.26 & 94.22 & 83.36 & 68.3 & 45.76 & 24 & 12.92 & 4.29 & 0 \\
\hline 29 & 207.11 & 129.02 & 93.29 & 74.16 & 48.4 & 37.82 & 28.73 & 16.78 & 3.09 & 0 \\
\hline 30 & 127.47 & 102.62 & 87.1 & 67.92 & 53.95 & 36.66 & 20.9 & 11.4 & 4.25 & 0.21 \\
\hline 31 & 149.75 & 105.08 & 75.16 & 47.9 & 41.6 & 26.8 & 23.56 & 17.02 & 10 & 2.58 \\
\hline 32 & 173.73 & 93.52 & 70.67 & 60.02 & 39.5 & 28 & 23.03 & 8.2 & 0.42 & 0 \\
\hline 33 & 216.75 & 139.4 & 110.92 & 84.5 & 54.05 & 38.34 & 25.04 & 9.92 & 0.81 & 0 \\
\hline 34 & 163.77 & 140.24 & 77.21 & 49.4 & 40.6 & 32.62 & 21.88 & 17.28 & 4.75 & 0 \\
\hline 35 & 134.84 & 103.48 & 67.18 & 47.8 & 35.55 & 29.96 & 24.6 & 8.28 & 1.8 & 0 \\
\hline 36 & 200.38 & 126.22 & 88.32 & 57.26 & 37.4 & 29.88 & 19.11 & 10.4 & 0.99 & 0 \\
\hline 37 & 113.04 & 77.92 & 59.18 & 34.14 & 29 & 20.04 & 15.44 & 10 & 8.7 & 1.55 \\
\hline 38 & 90.74 & 70.8 & 55.8 & 40.28 & 32.3 & 16.76 & 6.72 & 2.2 & 0 & 0 \\
\hline 39 & 143.56 & 62.78 & 33.2 & 21.82 & 14.3 & 6.16 & 8.16 & 0 & 0 & 0 \\
\hline 40 & 80.78 & 33.56 & 18.5 & 5.2 & 1.3 & 0 & 0 & 0 & 0 & 0 \\
\hline 41 & 47.46 & 18.52 & 13.2 & 4.68 & 2 & 0 & 0 & 0 & 0 & 0 \\
\hline 42 & 62.06 & 19.36 & 5.28 & 0.24 & 0 & 0 & 0 & 0 & 0 & 0 \\
\hline 43 & 0 & 0 & 0 & 0 & 0 & 0 & 0 & 0 & 0 & 0 \\
\hline 44 & 8.96 & 0 & 0 & 0 & 0 & 0 & 0 & 0 & 0 & 0 \\
\hline 45 & 10.3 & 0 & 0 & 0 & 0 & 0 & 0 & 0 & 0 & 0 \\
\hline 46 & 0 & 0 & 0 & 0 & 0 & 0 & 0 & 0 & 0 & 0 \\
\hline 47 & 0.24 & 0 & 0 & 0 & 0 & 0 & 0 & 0 & 0 & 0 \\
\hline 48 & 0 & 0 & 0 & 0 & 0 & 0 & 0 & 0 & 0 & 0 \\
\hline 49 & 0 & 0 & 0 & 0 & 0 & 0 & 0 & 0 & 0 & 0 \\
\hline 50 & 0 & 0 & 0 & 0 & 0 & 0 & 0 & 0 & 0 & 0 \\
\hline 51 & 0 & 0 & 0 & 0 & 0 & 0 & 0 & 0 & 0 & 0 \\
\hline 52 & 15.2 & 6.96 & 0 & 0 & 0 & 0 & 0 & 0 & 0 & 0 \\
\hline
\end{tabular}




\section{Evaluation of probability distribution technique}

The calculated observed and expected weekly maximum rainfall value and there goodness of fit value by Chie-square $\left(\chi^{2}\right)$ test for evaluating most suitable probability distribution. The three probability distribution techniques use for evaluation. The Gumble Distribution was found to most suitable for 7 days maximum rainfall because of showing lowest Chie square value as shown in table 1.

\section{Crop planning for up land}

Considering the rainfall at $80 \%$ probability level for crop planning in upland area. It was observed that appreciable amount of rainfall is available from $25^{\text {th }}$ to $38^{\text {th }}$ week. Maximum amount of rainfall which is $(17.28 \mathrm{~mm})$ expected to be available in $34^{\text {th }}$ week of the year which is based on 32 year data 19802011.Crop like Maize, Arhar, Groundnut, fodder crop etc. i.e. after one week of the perception of rain $25^{\text {th }}$ week. As $80 \%$ probability level there is less expected rainfall between $39^{\text {th }}$ to $52^{\text {nd }}$ week but that period is critical for late maturing variety of paddy there may be reduction in yield absence of irrigation, this absence of rainfall may facility the harvesting of early variety.

Different varieties rice crop such as Prabhat, Bhagvati, sown predominately. Pusa region soil and rainfall distribution is suitable for Tobacco cultivation at commercial level.

\section{Crop planning for low land area}

Crop planning for low land area at $80 \%$ probability level will be different than the upland because crop are lost by water logging or submergence in these area. The crop planning for this area can be done at $80 \%$ probability level early sowing of paddy (deep water paddy) can be done in $22^{\text {nd }}$ week of the year. Thus standing plant may be such that they can resist water logging. This is expected to be started from $25^{\text {th }}$ week at $80 \%$ probability level.

Long duration variety rice crop like Saroj, Rajendra Kasturi and Rajendra Subhasni may be suitable for low land area.

Based on the analysis of 32 years rainfall data of pusa, it was found that the maximum weekly observed rainfall by using Weibull method at $80 \%$ probability level was 17.28 $\mathrm{mm}$, similarly the value of maximum rainfall equal to $223,181,132,83.36,68.3,45.76$, $28.73,17.28$ and $10 \mathrm{~mm}$ were obtained at $10 \%, 20 \%, 30 \%, 40 \%, 50 \%, 60 \%, 70 \%, 80 \%$ and $90 \%$ probability level respectively. The expected maximum weekly rainfall values were computed using Log-Person Type-III distribution, Log-Person Normal distribution and Gumbel distribution for different probability levels it was found as $293.87 \mathrm{~mm}$, $300.59 \mathrm{~mm}$ and $301.57 \mathrm{~mm}$ respectively at $10 \%$ probability level among three probability distribution techniques for evaluation. The Gumble Distribution was found to most suitable for 7 days maximum rainfall at pusa. Considering the rainfall at $80 \%$ probability level for crop planning in upland area. It was observed that appreciable amount of rainfall is available from $25^{\text {th }}$ to $38^{\text {th }}$ week. Crop planning for low land area at $80 \%$ probability level will be different than the upland because crop are lost by water logging or submergence in these area. The crop planning for this area can be done at $80 \%$ probability level early sowing of paddy (deep water paddy) can be done in $22^{\text {nd }}$ week of the year. Thus standing plant may be such that they can resist water logging. This is expected to be started from $25^{\text {th }}$ week at $80 \%$ probability level. In pusa region for Kharif season rice crop varieties such as Prabhat, Bhagavati for up land and Saroj, Rajendra Kasutri, Rajendra Subhashni, for low land are may be suitable. For Rabi 
season wheat, Maize, Mustard, Rai, Tori, crop suitable for upland and lowland.

\section{References}

Bhakar, S. K., Bansal, A. K., Chhajed, N. and Purohit, R.C. (2007). Frequency analysis of consecutive days maximum rainfall at Banswara, Rajasthan, India. ARPN Journal of Engineering and Applied Sciences. 1(3): 64-67.

Chand, M., Kumar, D., Singh, D., Roy, N. and Singh S. K. (2011). Analysis of rainfall for crop planning in Jhasi district of Bandel Khand zone of U. P., India J. Soil Con. 39(1): 20-26.

Jhakhar, P., Gowda, H. C. H., Nail, B. S., and Baraman, D. (2011). Probability analysis of rainfall characteristics of Semliguda in Korapur, Orissia. Indian Journal of Soil Conservation. 39 (1): 912.

Panda, R. K., Naik, B. S., Gore, K. P., Mishra, P. K., Jakhar, P. and Gowda, H. (2009). Use of probability distribution models in rainfall analysis for post monsoon crop planning in eastern Ghat region of Orissa. Indian Journal of Dryland Agricultural Research and Development. 24(1): 75-80.

Singh, M., Kumar, J. Bhardwaj, S. S. (2009). Rainfall probability during dormant and growing seasons of apple in Himachal Pradesh. Journal of Agro Meteorology. 11(1): 47-50

\section{How to cite this article:}

Sanjay Kumar Nirala, Sushil Kumar Roy and Sujeet Kumar Bhagat. 2018. Evaluation of Probability Distribution Technique for Predication of Weekly Maximum Rainfall and Crop Planning for North Bihar. Int.J.Curr.Microbiol.App.Sci. 7(09): 2415-2422.

doi: https://doi.org/10.20546/ijcmas.2018.709.300 